\title{
フェノールフォーム複合材料の引抜成形法の開発 ${ }^{\dagger}$
}

\author{
邊吾 - * 荘司明子** \\ Development of Pultrusion Techniques of Phenolic Foam Composite
}

by

Goichi BeN $^{*}$ and Akiko SHOJI ${ }^{* *}$

Phenolic resin has originally advantages of heat proof, fire retardant and less smoke during burning and these advantages are suitable properties in the construction field. In this paper, we present a development of pultrusion technique of phenolic foam composite materials composed of phenolic resin foam as matrix and roving glass fibers as a reinforcement in order to apply this composite to materials in the field of construction. A pultrusion technique can produce composites having the same cross section and optional length, and it is very useful because the volume and arrangement of fibers in the cross section of composite can be almost kept constant. In the case of molding phenolic foam composites, it is important to control the foaming time, and the foaming time can be controlled by a certain environmental temperature under cooling and heating. Furthermore it is also important to feed constant resin, and we develop the original feeder machine.

Next, this paper also shows mechanical strengths of the phenolic foam composite comparing with those of the candidate materials in the construction. As a result, the phenolic foam composite shows a possibility of application in the field of construction like natural woods. Additionally, measurement results of the thermal conductivity and flammability of phenolic foam composite are also shown.

Key words : Pultrusion, Phenolic resin, Phenolic foam, Glass fiber, Mechanical strength, Thermal conductivity, Flammability

\section{1 緒言}

複合材料は多種多様な分野への応用開発が行われて打 り，その一つとして更なる軽量化を図るために樹脂の発 泡体を用いる研究が行われている。本研究は母材として フェノール樹脂を採用し，その発泡体とガラス繊維によ る複合材料の引抜成形法 ${ }^{1}$ を開発する。フェノール樹脂 は，耐熱性，難燃性，低発煙性といった特性を持ち，こ れらの利点は建築用構造材料として最適である。また， このフェノールフォーム複合材料はフォーム材の利点も あわせ持ち，軽量で衝撃吸収，断熱性に優れ，熱・炎に 強い新素材として, 軽量性, 安全性の求められる車両, 船舶, 航空機などの構造材分野, さらには発泡の膨張機 能に着目した宇宙構造分野への応用も期待できる。しか し, フェノール樹脂は, 不飽和ポリエステルなどと比較 して粘度が高くガラス繊維への含浸性に劣り，反応時に 水蒸気を発生するといった問題があるので，熱可塑性で はあるがノボラック型フェノール樹脂を用いて短繊維 FRPの小さな部品は，射出成形法によって製造されてい る. 本研究では, フェノールフォーム複合材料を成形す るため, 引抜成形法による連続的な成形技術の開発を目 的とする。目材が発泡剂を含んだ熱硬化性のフェノール 樹脂であることから, 引抜法で, 断面形状が大きく, 連 続瀻維を用いた FRTP の成形が可能であり，硬化時に水 蒸気によるボイドの発生も気にせずにすむと考えられる.
本研究で示すフェノールフォーム複合材料は，木材のよ うに釷での接合も可能な材料であり, 成形品の機械的強 度打よび釷引抜抵抗強度について報告する。また, 熱特 性として, 熱伝導率測定および燃焼特性試験の結果につ いても示す.

\section{2 成 形 法 の 概 要}

成形法は, 通常の引抜成形法 ${ }^{2}$ を基礎とし, 発泡体を 母材とする成形技術の開発を行った。したがって，引抜 方向に対して一定の断面形状を有し, 任意の長さの成形 部材を得ることが可能となる. 本研究で試作した成形機 を Fig. 1 に示す. 成形手順としては，フェノール樹脂の

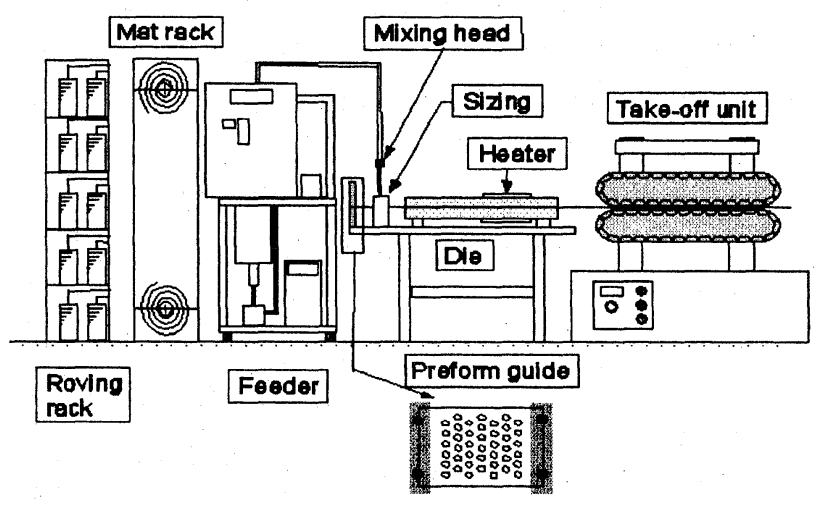

Fig. 1. Pultrusion facilities. 
定量かつ連続的な供給を確保しつつ，発泡が開始する前 にガラス繊維へ含浸させ，ダイ(金型) 内部で十分に発 泡し，速やかに硬化させなければならず，これら過程に おいての成形条件の㭘討を必要とする。

\section{3 樹脂の発泡硬化特性}

\section{1 発泡原理}

本研究に扔いて最も注意すべき点は，フェノール樹脂 の発泡・硬化過程であり, 引抜成形に適した発泡状態の 制御を行うための条件を検討した。本研究では，レゾー ル型フェノール樹脂（昭和高分子製 FOL-800）を使用 し，発泡方法は物理的発泡を採用した。発泡プロセスと しては，フェノール樹脂に発泡凨として塩化メテレンを 混合し，かく找する。つぎに硬化刘（昭和高分子製 FOH-801）を混合・かく抖することにより化学反応（架 橋反応）が起こり，硬化が開始し，粘度の上昇と同時に， 発生した反応熱で樹脂温度も上昇する。樹脂温度が内添

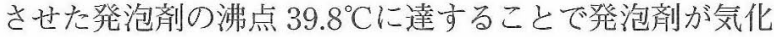
し，発泡が開始する。吕の間，硬化反応も進み，やがて 発泡と硬化が終了し, フェノールフォームが形成される。

\section{$3 \cdot 2$ 発泡・硬化特性}

樹脂の発泡開始時間はガラス繊維への含浸を考慮して 遅らせ，かつ発泡倍率を低下させずに速やかに発泡・硬 化することが理想である。発泡剛の沸点到達までの時間 を変えることで発泡開始を遅らせることが可能である。 そこで，フェノール樹脂単体の初期温度条件による発 泡・硬化特性を調べた。実験はフェノール樹脂 $100 \mathrm{~g}$ に 対して発泡剂 $11 \mathrm{~g}$ ，硬化剂 $22 \mathrm{~g}$ を容器中央部に熱電刘ワ イヤー（銅ーコンスタンタン）を接着した $500 \mathrm{ml}$ のポリ ビーカーに採り，2500rpmのかく拌機で 25 秒かく找し た後、ポータブルマルチ温度計を使用し発泡剂の沸点 $\left(39.8^{\circ} \mathrm{C}\right)$ に達するまでの時間を測定した。測定結果より 発泡開始時間扎よび発泡時間, 完全硬化後のフェノール フォームの発泡倍率をTable I に示す。発泡倍率は液状 樹脂の体積を 1 とし, 測定した発泡体の体積との比率を 計算した。

Table I より初期温度が低いほど発泡開始時間は幄く なるが，特に初期温度 $15^{\circ} \mathrm{C}$ 場合，発泡倍率も低下し発 泡時間，発泡時間ともに長くなってしまっている。これ は初期温度が低い場合，フェノ一ル樹脂の温度上昇が緩 やかなため, 発泡開始前に硬化反応が進み, 樹脂の粘度

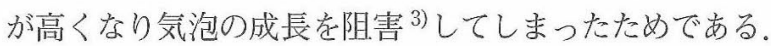

\section{$3 \cdot 3$ 環境温度による発泡・硬化特性の変化}

前節の結果をふまえ, 低い初期温度においても，発泡

Table I . Results of foaming process.

\begin{tabular}{|c||c|c||c|}
\hline $\begin{array}{c}\text { Initial } \\
\text { temperature } \\
{\left[{ }^{\circ} \mathrm{C}\right]}\end{array}$ & $\begin{array}{c}\text { Time till } \\
\text { foaming start } \\
{[\mathrm{sec}]}\end{array}$ & $\begin{array}{c}\text { Foaming time } \\
{[\mathrm{sec}]}\end{array}$ & $\begin{array}{c}\text { Expansion } \\
\text { ratio }\end{array}$ \\
\hline 15 & 212.5 & 137.4 & 13.3 \\
\hline 20 & 109.4 & 90.6 & 17.4 \\
\hline 25 & 58.3 & 91.7 & 17.9 \\
\hline
\end{tabular}

開始後の発泡を短時間で終了させるためにフェノール樹 脂の加熱実験を行った。実験は温度測定実験と同じ状況

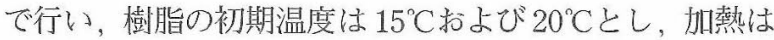
樹脂の発泡開始温度に達した時点で $60^{\circ} \mathrm{C}$ 浴槽に入れる 方法で行った。なお，浴槽による加熱は，発泡終了まで 行うものとした. Fig. 2 に $60^{\circ} \mathrm{C} の$ 加熱実験におけるフェ ノ一ル樹脂の温度変化示于。加熱開始直後, 樹脂温度 が急激に上昇し，反応が促進される。Fig. 2 の黑ぬりの 結果から，発泡から完全硬化までの時間は減少し，発泡 倍率が増加した。このように，発泡開始とともに環境温 度を上昇させることにより，発泡倍率を維持しつつ発泡 が開始するまでの時間（ポットライフ）を伸ばすことが 可能となり，引拻成形法に適した条件が特定された。

\section{$4 \cdot 1$ 定量吐出装置}

\section{4 連続引抜成形過程}

連続成形を扔こなうにあたり，成形品を均質に生産す るために樹脂の定量吐出装置を設計試作した。その原理 学Fig. 3 に示す。この吐出装置は，RIM 成形の原理孛 応用し，硬化剤および事前に発泡郕を内添したフエノ一 ル樹脂を別々に保持，室温以上の任意の温度で保温する ことが可能である。兄して，両タンクからモータポンプ を制御し各々を任意の比率で汲み上げ，吐出直前にミキ シングへッド内で混合かく找する仕組みになっている。 ミキシングヘッドは, Fig. 4 に示すように，タービュう ントミキサーとスタティックミキサーを併用して，静的 かく找でも発泡状態を向上させている。これにより，定 量的に吐出された樹脂はポットライフを経て，ダイ内部

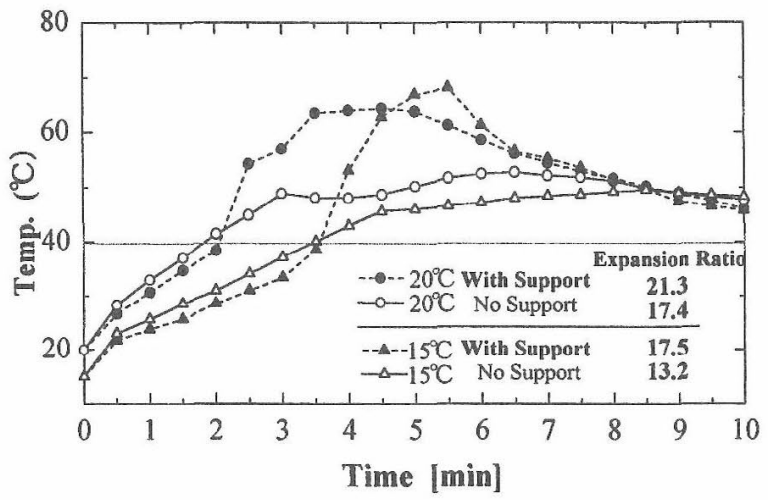

Fig. 2. Relation between time and foaming temperature (under $20^{\circ} \mathrm{C}$ and $60^{\circ} \mathrm{C}$ ).

Phenolic resin (with Foaming agent)

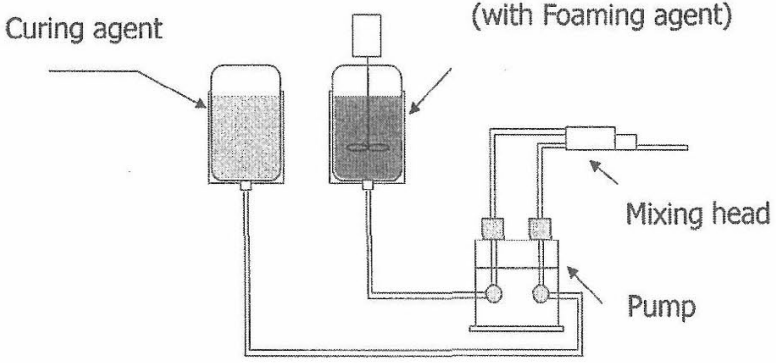

Fig. 3. Reaction injection system. 


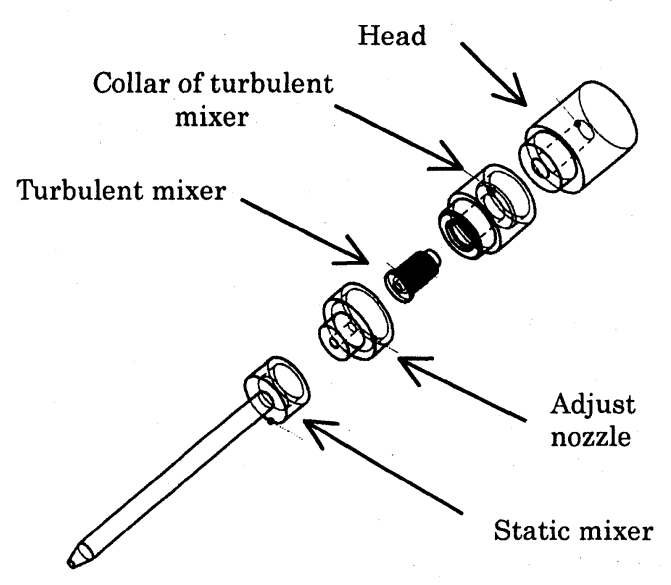

Fig. 4. Mixing head.

で連続的に発泡を開始する。前述のフェノール樹脂の発 泡・硬化条件から, 発泡剂, 硬化剂の樹脂に対する割 合はそれぞれ $11 \% 20 \%$ で混合し，供給するように設定 する。

\section{$4 \cdot 2$ 含浸過程}

ガラス繊維による強化を効果的に発生させるためには 繊維が樹脂に十分に含浸される必要がある。先に述べた 実験から，十分なポットライフを得るには定量吐出装置 内の樹脂温度を $20^{\circ} \mathrm{C} に$ 保てばよい。 また, フェノール樹 脂は粘度が高く, 吐出した樹脂をただガラスロービング に流しかけただけでは，含浸しない，また一般的な含浸 漕を使用した場合, 溜まった樹脂が発泡してしまい, 成 形できなくなる可能性が高い. そこで，Fig. 5 に示すよ うなサイジング型を使用した。サイジング型は，プリ フォームガイドとダイの間に設置し, 繊維を通す内壁に 溝を設け，ミキシングヘッドから吐出された樹脂が回り こんで含浸する仕組みになっている.さらに，数種類の ガラスロービングを使用して試作成形を行った結果，バ ルキーロービングの含浸度合いが良好であった。バルキ 一ロービングはダイレクトロービングをエアガンで散ら ばせたもので，かさ高さがあり，自重によって下方にか

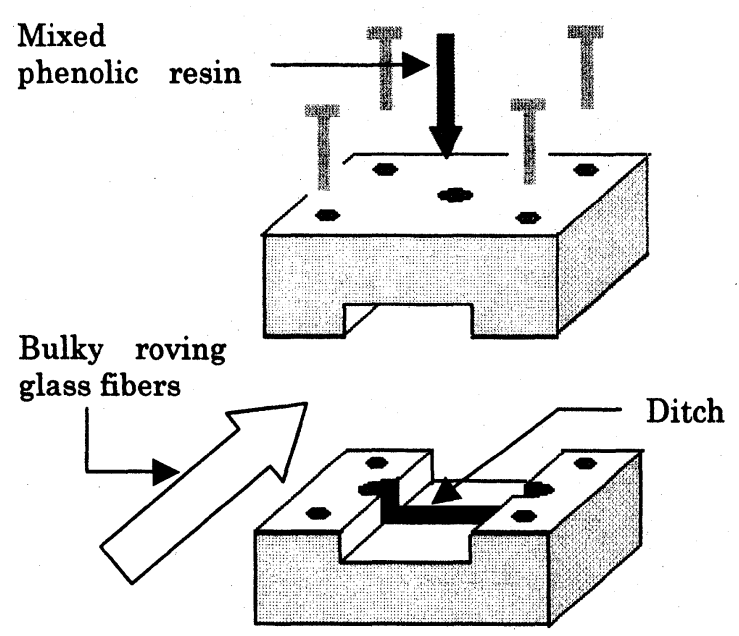

Fig. 5. Sizing mold.
たより，未含浸となるダイレクトロービングと比較して， 樹脂が繊維間に入り込みやすいと考えられる.

\section{$4 \cdot 3$ 吐出量の選定}

つぎに，発泡倍率を考虑した適切な樹脂の吐出量につ いての検討を行った，理想的には，成形品の目標比重， 強度，剛性を設定し，それにあわせた吐出量の決定とす べきだが，含浸過程に打いて紪維への十分な含浸に適し た吐出量を考慮する必要があり, 実験的に最適な值を検 討した．また，含浸には十分でも吐出量が多すぎると Fig. 6 に示すように, 成形品の成形長さに対して密度不 均一な材料となる。 これは, 余分な樹脂がダイ内での発 泡により引抜方向とは逆に流動するためと考えられる. この場合は, 引抜速度を早くすることで密度一定となる と予想されるが，吐出量を選定するため，引抜速度は一 定とし， $10 \mathrm{~cm} / \mathrm{min}$ の場合について検討した。実験は， 繊維体積含有率 $\mathrm{Vf}=6 \%$ として, 吐出量を変化させ試作 を行った。

Fig. 7 は, 成形品の密度と理論発泡倍率との関係を示 している，理論発泡倍率とは，吐出した樹脂の体積と金 型体積より算出し, 吐出量の逆数となる. 結果より, vf $=6 \%$ でかつ, バルキーロービングを使用した場合では, Fig. 7 に薄墨で示す範囲すなわち, 成形品密度が $0.4 \mathrm{~g} / \mathrm{cm}^{3}$ 程度となるよう樹脂を供給することで密度が安 定して成形できることが明らかになった。この範囲より 吐出量が少ないと, 成形品にガラス繊維の未含浸部が発 生し, 成形が不可能となる。ここで, 成形するフェノー ルフォーム複合材料の断面積を $52 \times 32 \mathrm{~mm}$ とした場合,

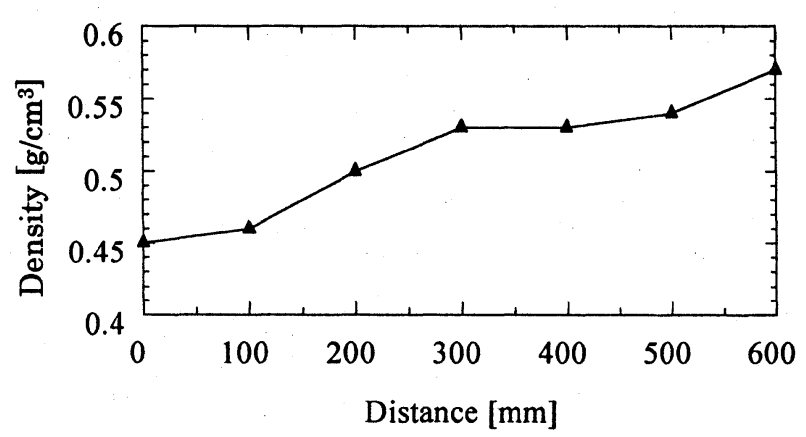

Fig. 6. Density distribution of molding direction.

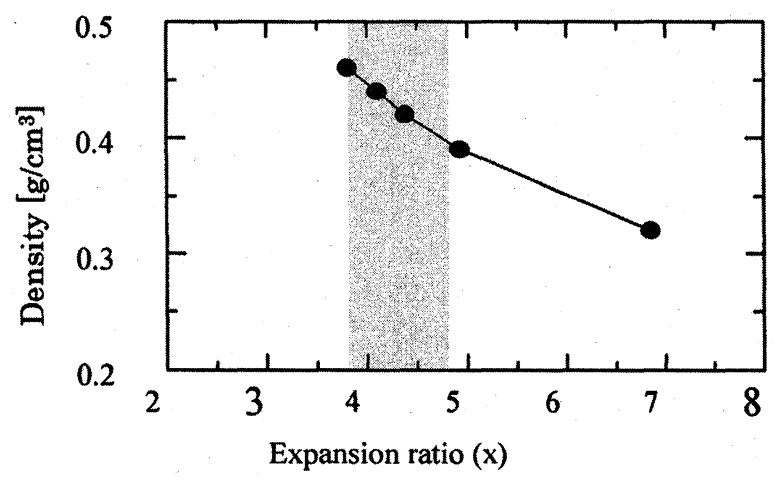

Fig. 7. Relation of density and expansion ratio. 
フェノール樹脂の吐出量は一分間に $30 \sim 40 \mathrm{~cm}^{3}$ として 成形を行うこととした。

\section{$4 \cdot 4$ ダイ温度設定}

Fig. 2 に示される温度变化と同様な温度分布を引抜成 形機のダイ内で再現できれば，ポットライフ内での含浸， 十分な発泡，す文やかな硬化が可能となる。そこで，ダ イの前半部 4 ケ所のパイプに水 $\left(22^{\circ} \mathrm{C}\right.$ 程度) を循環させ てダイ温度を下げ，後半部にヒーターを設置して $60^{\circ} \mathrm{Cに}$ 設定し,ダイ内壁の温度測定を行った。結果をFig. 8 に示 す. Fig. 2 と Fig. 8 を比較するとダイ内で, 温度サポー 卜を札ななた場合と同様の環境が再現できた。

次に，実際の成形時に，ダイ内部で樹脂がどのように 発泡しているかを確認するため, 成形品の表面付近と中 心部のガラス纎維に熱電対を固定し，成形時の樹脂温度 の変化を測定した結果を Fig. 9 に示す。Fig. 9 において 引抜方向の長さ $30 \sim 50 \mathrm{~cm}$ の実線部がヒーター設置部 分, 0 〜 $60 \mathrm{~cm} の \times$ で現した線がダイを示している。結 果より，ヒ一ター設置部で特に表面の樹脂温度が急上昇 し，発泡開始温度である $40^{\circ} \mathrm{Cに}$ 達していることがわかっ た。また，中心部では，樹脂の架橋反応䙪により泠却パ イプ部でも徐々に温度上昇している。しかし，いずれも ヒーター設置部で発泡開始温度に達していることが確認 でき,ダイの温度制卸が環境温度として作用し，意図し たと抢りの発泡・硬化が行われていることが確認できた。
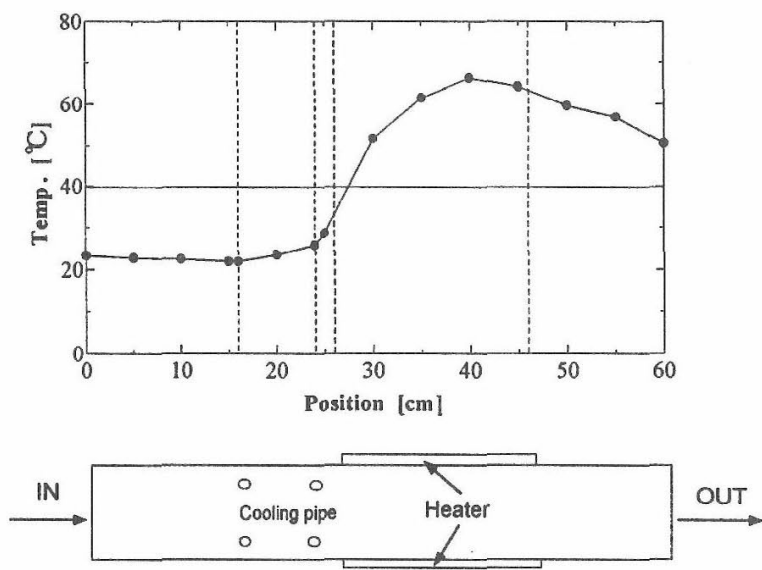

Fig. 8. Temperature distribution of die.

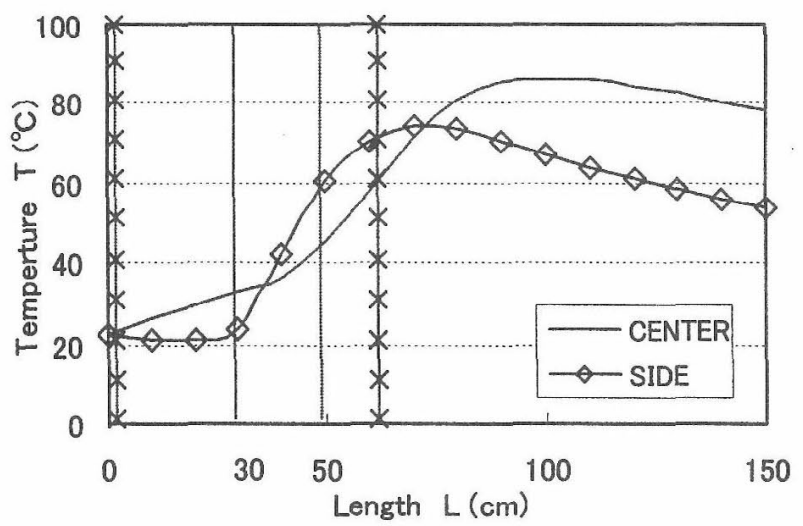

Fig. 9. Temperature change during molding.

\section{1 断面観察}

これまでに述べた成形法により，試作の段階では克る が, 巨視的に見てほぼ均質のフェノールフォ一ム複合材 料を連続的に成形することが可能となった。成形品断面 の様子をFig.10に示す。試作した成形品の断面を目視 で観察した結果，繊維束は全体に散布して频り，発泡も 全休に広がっており，金型断面形状どおりに成形されて いる。ガラス繊維への含浸状態は良好といえるが，若干， ロービング一本一本の繊維束の中心部に未発泡部分が確認 できる。兄こで, 成形品断面の様子を，高倍率レンズに よって観察した。200 倍のレンズで観察した結果を Fig. 11 に示す。左図は,内部の未発泡部分を示し，右図はロービ ング同士の間を撮影した結果である。この結果より，部 分的に発泡状態の違いが観察されたが，この原因は，強 化繊維として一本のロービングの結束が強いバルキー ロービングを使用したため，中心部では繊維同士の間㢳 が狭くなり発泡し難いものと考学られる。また, ロービ ング同士の間では, 㵶維の間隔がロービング内部よりは 広いため, 発泡しやすいと考えられる。このように, 発 泡セルの状態が部分的に異なることがわかった，今後は， かさ高さ異なるバルキーロービングを使用して，さらに 成形品の均質化を図りたい。

\section{$5 \cdot 2$ 機械的強度試験}

垷段階における成形品の力学的特性を詊晌し，今後の 成形方針をたてるため，V1 = 6\%における成形品の圧絔 試験扎よび曲げ試験を行った。試験片形状は，圧縮試験 は $32 \times 52 \times 100 \mathrm{~mm}$, 曲げ試験は $32 \times 52 \times 512 \mathrm{~mm}$, 支 点間距離は $448 \mathrm{~mm}$ として行った。試験機は，オートグ ラフ（最大試験力 $250 \mathrm{kN}$ ) を使用し, 試験方法はJIS Z 2101 村の試験方法に準拠して行った。その結果と

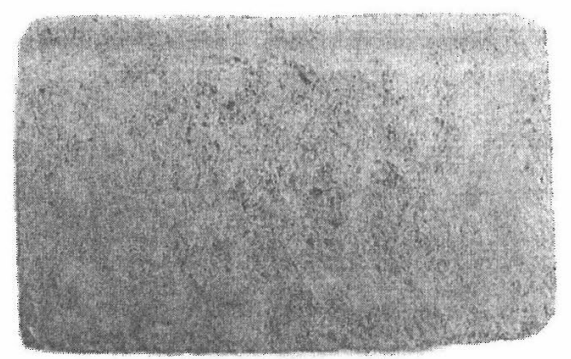

Fig. 10. Observation of a cross section.

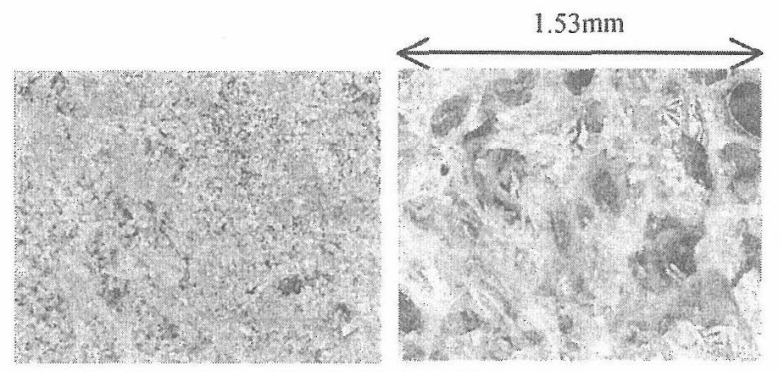

Fig. 11. Observation of a cross section $(\times 200)$. 
天然木材（杉）との比較を， Table II およびTable III に 示す. *は, 建築基準法施行令 95 条に定める基準材料 の強度を示す。 また, 釘引抜抵抗強度試験の結果につい て，杉との比較を Table IVに示す. Table IIより，フェ ノールフォーム単体の場合と比較してフェノールフォー ム複合材の圧縮強度は密度が若干大きくなるだけで， 4 倍近い強度が得られた。 また, 弾性率については 10 倍 近い值が得られ，ガラス䋊維補強の効果が現れている. また，側面方向の圧縮強度と，断面方向の圧縮強度との 比が杉とほぼ等しく，バルキーロービングによる成形品 は，杉と同様な異方性を有していることがわかる，成形 品の圧縮および曲げ強度は, 杉の圧縮, 曲げ強度には劣 るものの, 試作段階としては良好の值が得られた。しか し, 一般に発泡体の機械的強度は密度の影響が大きく, また発泡セルの状態にも左右 ${ }^{4)}$ れる。したがって，よ り均質な発泡の実現し, 繊維量を増加および繊維束を分 散させることで強度の改善が可能と考えられる．また，バ ルキーロービングは含浸性には優れているが，強度の面 ではダイレクトロービングに劣ると考えられるため，両 者を組み合わせれば，強度は向上すると期待できる。

つぎに建築構造材として木材と同様に用いる場合に必 要な特性の一つである釘引抜抵抗強度については，杉の

Table II . Compressive strength.

\begin{tabular}{|c|c|c|c|c|c|c|}
\hline & \multirow[b]{2}{*}{$\begin{array}{l}\text { Density } \\
{\left[\mathrm{g} / \mathrm{cm}^{3}\right]}\end{array}$} & \multirow{2}{*}{\multicolumn{2}{|c|}{$\begin{array}{l}\text { Compressive } \\
\text { strenght [MPa] }\end{array}$}} & \multicolumn{3}{|c|}{$\mathrm{L}$ direction } \\
\hline & & & & $\begin{array}{c}\text { Specific } \\
\text { strength } \\
{[\mathrm{m}]}\end{array}$ & $\begin{array}{c}\text { Compression } \\
\text { modulus } \\
\text { [MPa] }\end{array}$ & $\begin{array}{l}\text { Specific } \\
\text { modulus } \\
{[\mathrm{m}]}\end{array}$ \\
\hline Phenolic foam & 0.4 & \multicolumn{2}{|c|}{3.89} & 992 & 138 & $3.5 E+04$ \\
\hline \multirow{2}{*}{$\begin{array}{c}\text { Phenolic foam } \\
\text { composite }\end{array}$} & \multirow{2}{*}{0.42} & $\mathrm{~F}_{\mathrm{L}}$ & $F_{T}$ & \multirow{2}{*}{3484} & \multirow{2}{*}{1362} & \multirow{2}{*}{$3.3 E+05$} \\
\hline & & 14.3 & 0.67 & & & \\
\hline \multirow{2}{*}{ Cedar } & \multirow{2}{*}{0.33} & 27.4 & 0.68 & \multirow{2}{*}{8485} & \multirow{2}{*}{7355} & \multirow{2}{*}{$2.2 E+06$} \\
\hline & & $18.0^{*}$ & - & & & \\
\hline
\end{tabular}

Table III. Bending strength.

\begin{tabular}{|c||c|c|c|c|c|}
\hline & $\begin{array}{c}\text { Density } \\
{\left[\mathrm{g} / \mathrm{cm}^{3}\right]}\end{array}$ & $\begin{array}{c}\text { Bending } \\
\text { strength } \\
{[\mathrm{MPa}]}\end{array}$ & $\begin{array}{c}\text { Specific } \\
\text { strength } \\
{[\mathrm{m}]}\end{array}$ & $\begin{array}{c}\text { Bending } \\
\text { modulus } \\
{[\mathrm{MPa}]}\end{array}$ & $\begin{array}{c}\text { Specific } \\
\text { modulus } \\
{[\mathrm{m}]}\end{array}$ \\
\hline $\begin{array}{c}\text { Phenolic foam } \\
\text { composite }\end{array}$ & 0.42 & 18.95 & 4405 & 2015 & $4.7 \mathrm{E}+05$ \\
\hline Cedar & 0.33 & 63.74 & 19709 & 7355 & $2.3 \mathrm{E}+06$ \\
\cline { 2 - 6 } & $22.2^{\star}$ & 19706 \\
\hline
\end{tabular}

Table IN . Screw withdraw resistance.

\begin{tabular}{|c|c|c|c|}
\hline & & $\begin{array}{c}\text { Phenolic foam } \\
\text { composite } \\
{[\mathrm{Vf}=6 \%]}\end{array}$ & Cedar \\
\hline Density $\left[\mathrm{g} / \mathrm{cm}^{3}\right]$ & & 0.42 & 0.33 \\
\hline \multirow{2}{*}{$\begin{array}{c}\text { Screw withdraw } \\
\text { resistance }[\mathrm{N} / \mathrm{mm}]\end{array}$} & $T_{L}$ & 2.31 & 4.76 \\
\hline & $T_{T}$ & 4.89 & 5.86 \\
\hline
\end{tabular}

強度に近い值が得られた。これはガラス繊維にバルキー ロービングを使用したことによる効果が大きいと考えら れる．釘引抜抵抗強度についてもガラス繊維束の分散, および繊維量の増加によって, さらに向上すると考えら れる.

\section{$5 \cdot 3$ 熱伝導率測定試験}

フェノールフォーム複合材料の断熱性能として, 熱伝 導率の測定を行った。今回の試験のために準備した試験 体は, 引抜成形による $200 \mathrm{~mm}$ の長さのフェノールフォー 厶複合材料 $(\mathrm{Vf}=6 \%)$ をフェノール樹脂により接着し， 板状 $(200 \times 200 \mathrm{~mm})$ で, 厚さは $31.7 \mathrm{~mm}$ とし, $150^{\circ} \mathrm{C} て ゙$ 2 時間のポストキュアを行った. 試験には, 熱伝導率測 定装置を使用した。

Table Vに測定結果を示す，試験片密度は，接着に使 用した樹脂も含めた值であり, 引抜による成形品の密度 を括弧内に示す。 また, 比較として JIS A 9511 より抜粋 した断熱用フェノールフォーム単体およびウレタンフォー ムの熱伝導率を示す. 断熱材の発泡倍率は, 記載されて いなかったため, 推定值である. 熱伝導率は, 小さいほ ど断熱性能が高いことを示し，一般に発泡倍率が高い （密度が低い）ほど, 断熱性能は高くなる. Table Vより 断熱材として使用されている発泡体と比較して密度は約 10 倍だが, 熱伝導率は $2 \sim 3$ 倍程度であり, フェノール フォーム複合材料の断熱性能は十分に高いといえる.

\section{$5 \cdot 4$ 耐燃焼性試験}

次にフェノールフォーム複合材料の而燃焼性試験とし て, 発熱性試験を行った. 試験方法の概要としては, 輻 射電気ヒーターから試験体の表面に $50 \mathrm{~kW} / \mathrm{m}^{2}$ の輻射熱 を照射し, 同時に電気スパークを作動する。この時の試 験体からの排気ガスを採取し, 排気温度, 発熱量, 発熱 速度等を計測する。試験体は，側面と裏面をアルミニウ ム䇴で包んで，さらに裏面に無機繊維を充填してから， 試験体ホルダーに押し込むものとする，試験装置は, 燃 焼分析システム・コーンカロリーメータを使用した。試 験片は, 熱伝導率測定と同様のものと, その表面に鋼板

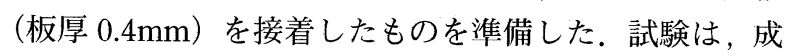
形品のみで 10 分間, 鋼板表面については, 10 分間の試 験で燃焼がほとんど見られなかったため, そのまま延長 して 20 分間の試験を行った. 試験体の構成および燃焼 試験結果を Table VIに示す. Table VIにおいて, 鋼板表 面の試験体の結果は, 20 分間の試験によって測定した值 である。また，それぞれの試験体について，試験開始か ら 10 分間の総発熱量 (THR), 最大発熱速度 (HRR), 煙

Table V. Thermal conductivity.

\begin{tabular}{|c|c|c|c|}
\hline & $\begin{array}{c}\text { Density } \\
{[\mathrm{g} / \mathrm{cm} 3]}\end{array}$ & $\begin{array}{c}\text { Expansion } \\
\text { ratio }\end{array}$ & $\begin{array}{c}\text { Thermal } \\
\text { conductivity } \\
{[\mathrm{W} / \mathrm{mK}]}\end{array}$ \\
\hline \hline $\begin{array}{c}\text { Phenolic foam } \\
\text { composite }\end{array}$ & $\begin{array}{c}0.476 \\
(0.437)\end{array}$ & 4.4 & 0.0668 \\
\hline Phenolic foam & 0.045 & $30 ?$ & 0.032 \\
\hline Urethane foam & 0.045 & $30 ?$ & 0.024 \\
\hline
\end{tabular}


Table VI. Flammability.

\begin{tabular}{|l|c||c|c|}
\hline \multicolumn{2}{|l|}{} & $\begin{array}{c}\text { Phenolic foam } \\
\text { composite }\end{array}$ & $\begin{array}{c}\text { Steel surfice }+ \\
\text { Composite core }\end{array}$ \\
\hline \hline Size & {$[\mathrm{mm}]$} & $100 \times 100$ & $100 \times 100$ \\
\hline Thickness & {$[\mathrm{mm}]$} & 31.5 & $0.4+31.6$ \\
\hline Mass & {$[\mathrm{g}]$} & 132.48 & 157.3 \\
\hline Vf & {$[\%]$} & 6 & $6($ core $)$ \\
\hline $\begin{array}{l}\text { Total heat } \\
\text { released }\end{array}$ & {$\left[\mathrm{MJ} / \mathrm{m}^{2}\right]$} & 20.56 & $0.89(20 \mathrm{~min})$ \\
\hline $\begin{array}{l}\text { Rate of heat } \\
\text { release(max) }\end{array}$ & {$\left[\mathrm{kW} / \mathrm{m}^{2}\right]$} & 76.22 & $6.05(20 \mathrm{~min})$ \\
\hline $\begin{array}{l}\text { Rate of heat } \\
\text { release(av.) }\end{array}$ & {$\left[\mathrm{kW} / \mathrm{m}^{2}\right]$} & 35.01 & $0.77(20 \mathrm{~min})$ \\
\hline $\begin{array}{l}\text { Mass loss rate } \\
{\left[\mathrm{g} / \mathrm{s} \cdot \mathrm{m}^{2}\right]}\end{array}$ & 2.581 & $1.023(20 \mathrm{~min})$ \\
\hline $\begin{array}{l}\text { Crack } \\
\text { (penetration) }\end{array}$ & & nothing & nothing (20min) \\
\hline
\end{tabular}

温度 (Smoke Temp), 質量 (Mass), 煙濃度 (Ext Coeff) の時間的な変化を Fig. 12 扩よび Fig. 13 に示す. 発熱速 度とは, 単位時間の発熱量の変化であり, 発熱速度が継 続して高くなる場合，火炎を展開させる恐れがある。 ま た, Fig. 12，13において，煙濃度については，わかりや すくするため 10 倍の值でプロットしている.

結果は, フェノールフォーム複合材料のみの場合につ いては, 試験開始 40 秒で発生した煙（ガス）に着火し たため, その時の最大発熱速度と, 煙濃度が急激に上昇 している，発熱速度は，瞬間的に上昇しただけであった が，その後も燃焼を続けたため，裏面に達するき裂はな いものの, 総発熱量および平均発熱速度は大きくなった。

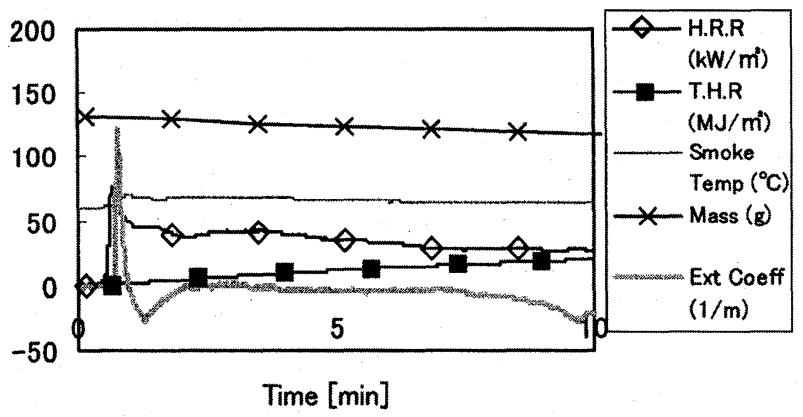

Fig. 12. Flammability of phenolic foam composite.

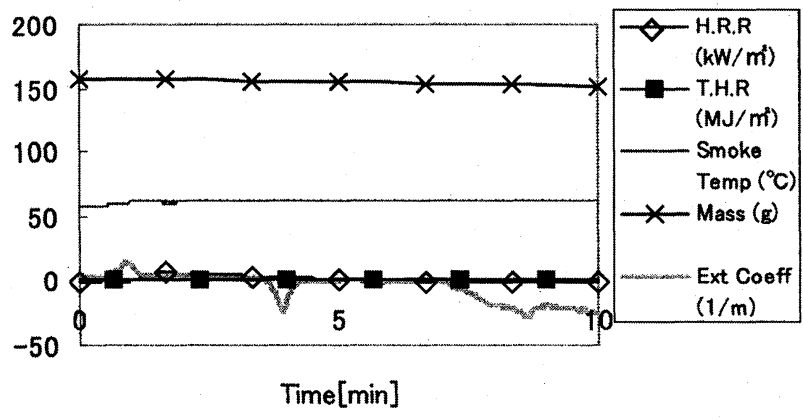

Fig. 13. Flammability of phenolic foam composite with steel surface.
一方，鋼板を表面に配置したものは，鋼板がふたのよう な役割を果たし，表面からのガス発生を抑え，燃焼はほ とんどせず，ホルダーと鋼板の隙間から発生したガスに ろうそく程度の火がついた状態となり，やがてその火も 消化してしまった。結果として総発熱量は，0.89MJ $/ \mathrm{m}^{2}$ と非常に低い值となった，以上より，難燃性能を向上さ せるためには，表面のガス発生をいかに押さえるかが重 要であると考えられる。

\section{6 結言}

フェノールフォーム複合材料の引抜成形法を開発する ため, フェノール樹脂の発泡・硬化実験の結果をもとに, ダイの温度分布を変化させ, 含浸領域と発泡・硬化領域 に分割することが有効であること，また，樹脂の連続的 な供給システムを導入し, バルキーロービングを使用す ることでサイジング型での連続成形が可能であることを 示した，さらに，断面形状 $52 \times 32 \mathrm{~mm}$ に打いて Vf $=6 \%$ に打ける適正な樹脂吐出量を検討し, 成形品密度が $0.4 \mathrm{~g} / \mathrm{cm}^{3}$ 程度で安定して成形できることを報告した。

成形品の力学的評価については, Vf $=6 \%$ の試作成形 品による圧縮試験抢よび曲げ試験等を行った結果, 天然 木材の強度には若干劣るものの, 建築用構造材料として の可能性を示した. 今後は, より効率的な含浸方法を検 討し, 纎維量, およびガラス䋊維束の分散を考慮して, より高品質な材料の成形法について, 検討したい。

次に，フェノールフォーム複合材料の熱伝導率につい ては， $0.0668 \mathrm{~W} / \mathrm{mK}$ であり，断熱性能が高いといえる. フェノールフォーム複合材料の耐燃焼性能試験より, 燃 焼の原因は，樹脂から発生するガスに着火するためであ り，表面からのガス流出をいかに防ぐかが決め手である と考元られる.また, 水酸化アルミ, クレイなどの添加 骩を加えるなど, 難燃性能の向上を図ることを今後の課 題としたい.

一緒に実験を行った日本大学大学院生滝本朋彦さん （現在，日本ゼオン(梀)）に多大な御助力をいただき，また (株ヴァンテックの小沢延行さんには, 引抜成形法に関す るご助言をいただいたことに感謝するとともに，実験 資材の便宜をはかっていただいた昭和高分子フェノール 樹脂研究所, 日東紡 FRP 研究所の皆様にお礼申し上げ ます。

\section{参 考 文 献}

1）邉 吾一, 青木義男, 滝本朋彦, 荘司明子, 第 31 回 FRP シンポジウム講演論文集，61（2002）。

2）プラスチック成形加工 cv 学会編，“先端成形加工技術”, p.345（1999）シグマ出版.

3）プラスチック成形加工学会編，“先端成型加工技術”，p.213 （1999）シグマ出版.

4）竹内 雍, “多孔質体の性質と吕の応用技術”, p.382（1999） フジテクノシステム。 